\title{
Role of GnRH in the maturation of pituitary gonadotroph function
}

\author{
R. N. Clayton \\ Department of Medicine, University of Birmingham, Edgbaston, Birmingham B15 2TH, U.K.
}

\section{Introduction}

Since the characterization and synthesis of the hypothalamic decapeptide, gonadotrophin-releasing hormone (GnRH), which stimulates the release of LH and FSH from the pituitary gland, much information has been obtained that confirms the importance of this peptide in the control of reproduction. Most studies have focussed on the in-vivo effects of $\mathrm{GnRH}$ on gonadotroph function and reproductive processes in adult rodents, sheep, monkeys and humans. In addition to the stimulatory action of GnRH on pituitary gonadotrophs, the peptide has been shown to stimulate and inhibit steroidogenesis in the testes and ovaries of rats (Sharpe, Fraser, Cooper \& Rommerts, 1982) and this suggests that it exerts, in this species at least, a paracrine modulatory function within the gonads. As yet, however, no convincing evidence for a direct gonadal action of GnRH in other species has been obtained. Indeed, the precise chemical identity of 'gonadal GnRH' remains elusive and a similarity with the hypothalamic decapeptide has not been confirmed. For this reason this review will not consider further the role of 'gonadal' GnRH-like material in sexual maturation.

There is relatively little information on the importance of $\mathrm{GnRH}$ during the differentiation and maturation of the functional activity of the gonadotrophs, although this is a continuous process which is subject to modification as gonadal feedback regulatory influences change with progressive maturation of the animal up to and through puberty. The present review concentrates upon the role of GnRH in these developmental and maturational events of pituitary gonadotroph function in rodents. More comprehensive reviews of pubertal development may be found elsewhere (Kaplan, Grumbach \& Aubert, 1976; Odell \& Swerdloff, 1976; Styne \& Grumbach, 1978; Ojeda, Andrews, Advis \& Smith-White, 1980).

\section{GnRH and gonadotroph differentiation in the fetus}

Araki, Toran-Allerand, Ferin \& Vande Wiele (1975) studied the content of GnRH in the hypothalamus of the rat fetus during gestation and found none until the day of birth. However, using a highly specific antiserum against $\mathrm{GnRH}$ and a very sensitive radioimmunoassay, Chiappa \& Fink (1977) found measurable immunoreactive GnRH, although in very low concentrations, in hypothalamic extracts from rat fetuses from 15 days of gestation onwards. As in the study of Araki et al. (1975), there was a progressive increase in hypothalamic GnRH content during post-natal development in male and female rats (Chiappa \& Fink, 1977), although the GnRH content in females had decreased by the time of the first pro-oestrus. In a re-evaluation of the role of $\mathrm{GnRH}$ in the differentiation of gonadotrophs, Aubert et al. (1985) detected immunoreactive GnRH in whole rat brain as early as 12 days of gestation. The amount remained low and constant between 12 and 17 days of gestation but then increased markedly. In human fetuses GnRH is detectable in the hypothalamus as early as 70 days of gestation (Kaplan et al., 1976).

Although the hypophysial portal vasculature is not fully developed in the rat until 7 days of age (Glydon, 1957), electron microscope studies of the fetal median eminence show nerve terminals 
in close proximity to the perivascular spaces above the pituitary primordium as early as 16 days of gestation (Fink \& Smith, 1971). It is therefore possible that GnRH produced in the hypothalamus reaches the developing gonadotrophs by simple diffusion.

Immunoreactive LH and FSH are detectable in pituitary homogenates from male fetal rats from 17 days of gestation onwards, but not in pituitary homogenates from female fetuses (Chowdhury \& Steinberger, 1976). Chiappa \& Fink (1977) detected LH, but not FSH, in pooled pituitary homogenates from both sexes from Day 17 of gestation. However, Nemeskeri, Halasz \& Kurcz (1983) and A. Nemeskeri \& R. N. Clayton (unpublished) have shown that LH can be detected as early as 15 days of gestation and FSH from 19 days onwards. Immunocytochemical staining with antiserum to rat LH of pituitary glands from fetuses of 17 days of gestation was positive, and in fetuses at 18 days positive cells were observed after staining with an antiserum against the subunit of pig LH (Begeot, Dupouy, Dubois \& Dubois, 1981). The similarity in the timing of the appearance of immunoreactive GnRH and LH in the fetal hypothalamus and pituitary respectively suggests that GnRH may be important for the synthesis of gonadotrophins by the fetal pituitary. A further point in favour of a causal relationship between endogenous hypothalamic GnRH and the differentiation of gonadotrophs is the appearance at 16 days of gestation of pituitary receptors for GnRH (Aubert et al., 1985; R. N. Clayton \& A. Nemeskeri, unpublished data). GnRH receptors could not be reliably detected before this age despite pooling of a large number of pituitary glands. The number of pituitary $\mathrm{GnRH}$ receptors increased progressively from 16 days of gestation until birth in parallel with an increase in pituitary weight and gonadotrophin content. Although Aubert et al. (1985) reported the measurement of GnRH receptors in rat pituitaries at 12 days of gestation the concentration remained barely detectable until 15-16 days; thereafter a marked increase occurred.

Direct evidence for a role of $\mathrm{GnRH}$ in the development of gonadotrophs in rats has come from experiments in which pituitary primordia removed on Day 12 of gestation were maintained in explant culture for 9 days in the presence or absence of GnRH. At the end of this time only those explants treated with GnRH stained positively for immunoreactive LH (Begeot, Dubois \& Dubois, 1984). However, pituitary tissue removed at Day 14 of gestation and maintained for 7 days in culture in the absence of added GnRH also appeared to show differentiated gonadotrophs when examined by immunocytochemistry. There therefore appears to be a critical time between 12 and 14 days of gestation when GnRH is essential for differentiation of gonadotrophs but after Day 14 it is apparently not an essential requirement. Further evidence for this critical and early requirement for GnRH is provided by the fact that at birth the pituitary glands of fetuses encephalectomized at 16 days of gestation contain the normal number of LH-staining cells (Begeot et al., 1981).

Additional evidence for a role for $\mathrm{GnRH}$ in the differentiation of gonadotrophs is provided by the observation that the pituitary glands of anencephalic fetuses contain very little gonadotrophin and are unresponsive to GnRH (Kaplan et al., 1976).

Whilst the available data suggest a role for $\mathrm{GnRH}$ in the differentiation of gonadotrophs, the source of this GnRH remains obscure since gonadotrophin-containing cells are present in the hypogonadotrophic hypogonadal ( $h p g$ ) mouse which supposedly has no endogenous hypothalamic GnRH (Cattanach, Iddon, Charlton, Chiappa \& Fink, 1977; McDowell, Morris \& Charlton, 1982). Exogenous GnRH markedly increases the size of gonadotrophs as well as the gonadotrophin content in hpg mice (McDowell, Morris, Charlton \& Fink, 1982). In the hpg mouse, therefore, there may be sufficient hypothalamic GnRH or a GnRH-like peptide, albeit undetectable in tissue extracts by radioimmunoassay, to effect differentiation and a very limited synthesis of gonadotrophin. Alternatively, extra-hypothalamic GnRH may be important in gonadotroph differentiation. GnRH-like immunoreactivity and bioactivity have been identified in human placental tissue as early as 12 weeks of gestation (Siler-Khodr \& Khodr, 1978; Khodr \& Siler-Khodr, 1980) and de-novo synthesis of GnRH by the human placenta at term has also been reported (Tan \& Rousseau, 1982). However, there are no reports to date of GnRH-like material in rat placental tissue (Aubert et al., 1985). Nevertheless, the possibility exists that a placental GnRH- 
like peptide could direct gonadotroph differentiation. This would reconcile the observations of the GnRH-deficient hpg mouse with the other evidence that supports the fact that GnRH is crucial to the differentiation and maturation of gonadotrophs.

\section{Post-natal development of gonadotrophin secretion and pituitary responsiveness to GnRH}

The profiles of gonadotrophin secretion during post-natal development are being continually modified by changes in the feedback sensitivity of the hypothalamus-pituitary system to gonadal steroids.

\section{Male rats}

In male rats serum LH and FSH concentrations tend to be high during the neonatal (0-7 days of age) period (Döhler \& Wuttke, 1974) but in the infantile-juvenile period (8-30 days of age) there is no consistent pattern of LH secretion. Some authors report a gradual decline in LH concentrations up to the onset of puberty (Chan, Clayton, Knox \& Catt, 1981; Miyachi, Nieschlag \& Lipsett, 1973), whilst other studies describe no major change (Döhler \& Wuttke, 1974; Ketelslegers, Hetzel, Sherins \& Catt, 1978; Dalkin, Bourne, Pieper, Regiani \& Marshall, 1981). However, Negro-Vilar, Krulich \& McCann (1973) observed a gradual doubling of serum LH concentrations between 20 and 100 days of age. There is therefore no consistent change in pituitary LH output with sexual maturation in male rats. In contrast, an increase in FSH secretion is consistently observed with peak values occurring between Days 20 and 35 of age (Negro-Vilar et al., 1973; Miyachi, Nieschlag \& Lipsett, 1973; Döhler \& Wuttke, 1974; Ketelslegers et al., 1978; Dalkin et al., 1981; Chan, Clayton, Knox \& Catt, 1981). This increased secretion of FSH is responsible for the rapidly increased rate of testicular growth starting about 20 days of age, and the acquisition of testicular receptors for LH and FSH (Ketelslegers et al., 1978). The FSH-dependent increase in LH receptors enhances the sensitivity of the testes to unchanged concentrations of serum $\mathrm{LH}$ and initiates a rise in the production of testosterone (Ketelslegers et al., 1978).

Pituitary responsiveness to exogenous $\mathrm{GnRH}$ in male rats shows a tendency to increase gradually as development proceeds (Debeljuk, Arimura \& Schally, 1972a; Dullaart, 1977) although an age at which there is a dramatic increase in sensitivity has not been identified.

The content of pituitary receptors for GnRH in male rats increases steadily from birth to 30 days of age when a plateau is reached. This is paralleled closely by an increased pituitary LH content (Chan et al., 1981). When expressed as a concentration, receptor values double between birth and 15 days of age. The value then remains high until Day 35, when it begins to decline and reaches adult values on Day 80 after birth (Chan et al., 1981; Dalkin et al., 1981). The decline in GnRH receptor concentration is mirrored by increasing serum testosterone concentrations, suggesting that an increased negative feedback action of gonadal hormones may cause a reduction in GnRH receptors either secondary to an inhibition of endogenous GnRH secretion (Chan et al., 1981) or by a direct inhibitory action of testosterone on the gonadotrophs (Giguere, Lefebvre \& Labrie, 1981).

Despite the increased concentration of GnRH receptors in juvenile rats (15-35 days of age) there is no apparent increase in responsiveness to exogenous GnRH. Nevertheless, the doses of exogenous GnRH used were high and probably well above the 'physiological' endogenous GnRH levels reaching the pituitary gland. It may well be that the increased number of receptors confers sensitivity to 'physiological' GnRH stimulation. It is perhaps significant that the highest serum concentrations of FSH are observed between these same ages in male rats when GnRH receptor concentration is maximal.

In the only study to examine changes in pituitary $\mathrm{GnRH}$ receptor after gonadectomy during sexual maturation the expected rise in pituitary $\mathrm{GnRH}$ receptors was observed in male rats 
castrated up to 25 days of age, but after castration between Days 30 and 45 no increase was seen despite a marked rise in the serum LH concentration (Duncan, Dalkin, Barkan, Regiani \& Marshall, 1983). In 35-45-day-old male rats a higher dose of exogenous GnRH was required to induce $\mathrm{GnRH}$ receptors, indicating that at this age an alteration in the regulation of hypothalamic $\mathrm{GnRH}$ secretion is responsible for the failure of orchidectomy to increase the number of $\mathrm{GnRH}$ receptors.

\section{Female rats}

Serum LH concentrations are high in female rats during the neonatal period and then decline to stable levels by about 20 days of age (Döhler \& Wuttke, 1975; Chan et al., 1981; Dalkin et al., 1981). The concentrations of serum FSH, as in male rats, rise characteristically between Days 10 and 20 of age with a peak value at Day 15 (Ojeda et al., 1980; Chan et al., 1981; Dalkin et al., 1981). The rise in FSH in females does not appear to be as prolonged as in male rats, but there is a striking increase in pituitary sensitivity to GnRH in the juvenile female, with maximum concentrations of LH and FSH on Days 15-20 of age (Debeljuk et al., 1972b; Ojeda, Jameson \& McCann, 1977; Dullart, 1977). The increased sensitivity to GnRH is probably responsible for the high FSH concentrations at these ages and correlates well with the increased concentration of pituitary GnRH receptors that are maximal between Days 10 and 25 of age in female rats (Chan et al., 1981; Dalkin et al., 1981). The GnRH receptor concentration then falls rapidly to a nadir between 40 and 50 days of age, just after vaginal opening which occurs about Day 37-38 of age. The increase in GnRH receptors from birth to maximum values at 15 days of age (a 3-fold rise) is greater than that in males (a 2-fold rise) which may account for the enhanced pituitary sensitivity to GnRH found in juvenile females but not in males. There was no inverse correlation between the decline in GnRH receptors and serum oestradiol concentrations in female rats (Chan et al., 1981), since the latter remained constant after 30 days of age. Before this time high concentrations of $\alpha$-fetoprotein in serum cause elevated total serum oestradiol concentrations in female rats. Again, unlike events in male rats, there was no time before puberty when GnRH receptors failed to increase after ovariectomy (Duncan et al., 1983). The study by Duncan et al. (1983) further emphasized the increased sensitivity of the immature gonadotroph because serum LH and FSH rises after ovariectomy were greatest at 15-20 days of age.

In developing rats of both sexes, therefore, a common finding is the infantile/juvenile increase in serum FSH concentrations, which serves to initiate gonadal steroidogenesis. This rise in FSH may be a consequence of increased pituitary sensitivity to GnRH contributed to by an increased pituitary content of GnRH receptors. Whether this latter occurs as a result of increased hypothalamic GnRH output at this stage of development is unknown, although it remains a possibility.

\section{Role of GnRH in post-natal development of the pituitary-gonadal axis}

\section{Blockade of GnRH action}

Passive or active immunization of adult animals against GnRH is followed by hypogonadotrophic hypogonadism, with infertility in males and disruption of ovarian cyclicity in females (see Fraser, McNeilly \& Popkin, 1984, for review). The effect of transient deprivation of gonadotrophin secretion on testicular function in rats was examined at 100 days of age after passive immunization at 5 days of age. Testicular weight, seminiferous tubular diameter, seminal vesicle weight, testicular LH receptors, androgen binding protein production, and fertility are all reduced although serum concentrations of $\mathrm{LH}, \mathrm{FSH}$, prolactin and testosterone are normal (Bercu, Jackson, Sawin, Safaii \& Reichlin, 1977). The establishment of testicular functions, particularly those that are FSH-dependent (i.e. tubular growth and Sertoli cell function), was permanently 
impaired when GnRH support for gonadotrophin secretion was eliminated before 15 days of age (Bercu et al., 1977; Bercu, 1982; Vogel, Gunsalus, Bercu, Musto \& Bardin, 1983). At this time of neonatal-juvenile development, serum FSH concentrations are highest and it is likely that it is the removal of this hormone that is most detrimental to the growing testis, a view supported by the finding that immunization of neonatal rats with an anti-LH serum is not accompanied by permanently impaired seminiferous tubular growth (Goldman, Quadagno, Shryne \& Gorski, 1972).

In juvenile rats aged 23-32 days, we were unable to show a marked effect of passive immunization against GnRH on testicular maturation, probably because the antiserum did not completely eliminate gonadotrophin secretion (Huhtaniemi, Stewart, Channabasavaiah, Fraser \& Clayton, 1984a), even though an equivalent dose per unit body weight of anti-GnRH serum was effective at suppressing serum gonadotrophins, testosterone, and accessory sex-organ weight in adult male rats (Huhtaniemi et al., 1984b). However, by continuous infusion of a GnRH antagonist analogue for 7 days we were able to suppress completely all aspects of gonadal development between 23 and 32 days. This was associated with undetectable serum LH and FSH values (Huhtaniemi et al., 1984a). We do not know whether testicular function would have recovered since the animals were not followed until sexual maturity, although the prediction would be that at this stage of juvenile maturation arrest of gonadotrophin-dependent gonadal functions would be temporary and fully recoverable. Nevertheless, the approach using a GnRH antagonist clearly showed the dependence of testicular maturation on endogenous gonadotrophins, and the importance of GnRH.

\section{$G n R H$ replacement in $G n R H$-deficient states}

While counteracting the action of $\mathrm{GnRH}$ is one way to assess the contribution of the peptide to sexual maturation, another approach is to examine the effect of treatment of GnRH-deficient animals with GnRH (Cattanach et al., 1977).

In an extensive study of the effects of GnRH in the hpg mouse, Charlton et al. (1983) evaluated various $\mathrm{GnRH}$ treatment schedules. Whilst once daily administration of GnRH to male $h p g$ mice normalized pituitary FSH content, increased testicular weight, and induced spermatogenesis, there was no change in pituitary $\mathrm{LH}$ content or seminal vesicle weight. This indicates that limited GnRH stimulation of gonadotrophs preferentially activates FSH synthesis and its subsequent release. However, when small doses of GnRH were given every $2 \mathrm{~h}$, pituitary LH content and seminal vesicle weight were also stimulated, indicating the critical nature of frequent intermittent stimulation of gonadotrophs for the synthesis and release of LH. This same pulsatile GnRH regimen also stimulated pituitary GnRH receptors which increased before the major increase in pituitary and serum FSH concentrations, suggesting that their induction was required for maturation of gonadotroph function (Young, Speight, Charlton \& Clayton, 1983). These studies also demonstrated the same pattern of early activation of FSH synthesis followed by that of LH as occurs during the development of gonadotrophs in animals with their own input of GnRH.

In female $h p g$ mice single daily injections of $\mathrm{GnRH}$ produced above normal values for pituitary FSH contents but there was no clear evidence of ovarian steroidogenesis since uterine weights did not alter. In contrast, multiple injections of $\mathrm{GnRH}$ resulted in uterine growth. An additional advantage of this animal model is the ability to study gonadal steroid feedback interactions with known and defined inputs of GnRH at the level of the pituitary gland, without any consideration being given to the hypothalamus as a site of feedback control. It has been clearly shown that oestradiol significantly attenuates the pituitary FSH response to pulsatile GnRH treatment, whilst ovariectomy enhances this. These data show that oestrogens clearly exert negative feedback at the level of the pituitary gland, which has now been shown to be due to inhibition of FSH and LH gene transcription and/or mRNA translation or processing (Alexander \& Miller, 1982; Nilson, Nejedlik, Virgin, Crowder \& Nett, 1983; Counis, Corbani \& Jutisz, 1983).

The pituitary hormonal changes in $h p g$ mice treated chronically with GnRH are accompanied 
by marked ultrastructural changes in the gonadotrophs. While there was some increase in the proportion of pituitary cells containing immunoreactive $\mathrm{LH}$, a more striking change was the increase in the surface area, granule content, size of the rough endoplasmic reticulum and Golgi apparatus of the gonadotrophs (McDowell et al., 1982). These changes all regressed after cessation of GnRH treatment, indicating that $\mathrm{GnRH}$ is a true trophic hormone whose continued presence is essential for normal morphology of the gonadotrophs.

An equally dramatic effect on the gonadotroph-gonadal axis was observed in $h p g$ mice with grafts of fetal hypothalamic tissue in the third ventricle. The hypogonadism in male (Krieger et al., 1982) and female (Gibson et al., 1984; Young, Detta, Clayton, Jones \& Charlton, 1985) hpg recipients was reversed. Although female $h p g$ mice with hypothalamic grafts do not appear to exhibit cyclic ovarian activity they are able to mate (Gibson et al., 1984). The intracerebral grafting of hypothalamic tissue has potential for examination in the host of neural regulation of the implanted tissue with respect to GnRH release. In addition, it is less tedious than repetitive treatment with exogenous GnRH. However, it still remains to be seen which method of GnRH stimulation of the pituitary gland will produce the best overall physiological response.

\section{Role of GnRH in the initiation of cyclic ovarian activity}

There is now compelling evidence that GnRH is released from the hypothalamus as discrete pulses, about every $2 \mathrm{~h}$, rather than in a continuous trickle (Knobil, 1980; Clarke \& Cummins, 1982; Levine, Pau, Ramirez \& Jackson, 1982). Since GnRH cannot be reliably measured in the peripheral circulation, statements concerning endogenous $\mathrm{GnRH}$ release are made on the basis of frequent measurements of serum LH concentrations which show peaks and troughs that are assumed to represent previous activation of the pituitary by endogenous GnRH (reviewed by Knobil, 1980). This assumption is probably valid since Clarke \& Cummins (1982) have shown in the same sheep simultaneous peaks of GnRH in portal blood and of $\mathrm{LH}$ in blood from the jugular vein. In adult monkeys in which hypothalamic GnRH secretion was abolished by ablation of the median eminence, normal ovulatory ovarian cycles and pregnancy were restored by hourly pulses of GnRH (Knobil, 1980). Similarly, ovulation and pregnancy can be induced in women with permanent isolated gonadotrophin deficiency, or in whom this is temporary, and potentially reversible, due to loss of body weight (hypothalamic amenorrhoea) (Crowley \& McArthur, 1980; Mason et al., 1984; Menon, Butt, Clayton, Logan-Edwards \& Lynch, 1984).

The question therefore arises as to whether acquisition of this pulsatile pattern of GnRH secretion is the critical determinant of cyclic pituitary-ovarian function. Evidence to support such a conclusion has been obtained from prepubertal monkeys treated with hourly pulses of GnRH. These animals developed normal cyclic pituitary-gonadal function, including the positive feedback response to oestrogen and ovulation, which reverted to ovarian quiescence once pulsatile GnRH treatment was stopped. Subsequently, these same animals spontaneously developed regular ovarian cycles (Wildt, Marshall \& Knobil, 1980). These data show that the pituitary gland and ovary of the prepubertal animal are able to respond to 'appropriate' stimulation from the hypothalamus and that neither the ovary nor the pituitary gland is a limiting factor for the initiation of cyclic ovarian function. This view has been supported by determination of $\mathrm{LH}$, and by inference GnRH, pulsatility in humans with gonadal dysgenesis. In prepubertal individuals LH pulses were very infrequent and their amplitude very low, indicating very little endogenous GnRH secretion. In individuals of pubertal age the most striking change was the big increase in the frequency and amplitude of LH pulses during sleep. As the individuals progressed through puberty to adulthood LH pulses became more frequent during the day (Ross, Loriaux \& Cutler, 1983). This study provides strong evidence that the critical determinant of puberty in primates is the 'switching-on' and the steady progressive acceleration of the hypothalamic GnRH pulse generator. Although unproven, it is highly likely that a similar mechanism operates to initiate puberty in nonprimate species, including rodents. Direct evidence that hypothalamic GnRH pulsatility can 
change with development has been provided by examination of pulsatile $\mathrm{GnRH}$ release in vitro from intact medial basal hypothalami of rats: as the donor age increased (19-50 days) so did GnRH pulse frequency (Bourguignon \& Franchimont, 1984).

\section{Conclusions}

It is clear that the decapeptide GnRH is central to the normal post-natal maturation of gonadotroph function and that the neural control of $\mathrm{GnRH}$ secretion provides the key to our understanding of the acquisition of reproductive competence in mammalian species. Indeed, $\mathrm{GnRH}$ is also responsible for reproductive competence in birds, reptiles, and fishes and in these vertebrates the amino acid sequence is highly conserved with only one or two amino acid differences in the C-terminal end of the molecule (King \& Millar, 1979, 1980; Millar \& King, 1983; Sherwood et al., 1983). These data indicate that $\mathrm{GnRH}$ has been highly conserved as a reproductive hormone during evolution and is phylogenetically ancient. Loumaye, Thorner \& Catt (1982) have drawn attention to the similarity of GnRH with the tridecapeptide $\alpha$-mating factor of a unicellular yeast. This yeast tridecapeptide has weak GnRH agonist activity in mammalian pituitary cells (Loumaye et al., 1982) and perhaps represents a phylogenetically much earlier reproductive hormone. The use of small peptides as signals between unicellular organisms attests to their very fundamental function. As more complex organisms evolved so too did the hierarchy of secondary (pituitary gland) and tertiary (gonadal or other target and organ) hormonal messengers.

\section{References}

Alexander, D.R. \& Miller, W.L. (1982) Regulation of ovine follicle stimulating hormone $\beta$-chain mRNA by $17 \beta$-estradiol in vivo and in vitro. J. biol. Chem. 257 , 2282-2286.

Araki, S., Toran-Allerand, C.O., Ferin, M. \& Vande Wiele, R.L. (1975) Immunoreactive gonadotropin-releasing hormone ( $\mathrm{GnRH}$ ) maturation in the rat: ontogeny of regional hypothalamic differences. Endocrinology 97, 693-698.

Aubert, M.L., Begeot M., Winiger, B.P., Morel, G., Sizonenko, P.C. \& Dubois, P.M. (1985) Ontogeny of hypothalamic GnRH and pituitary GnRH receptors in fetal and neonatal rats. Endocrinology 116, 1565-1576.

Begeot, M., Dupouy, J.P., Dubois, M.P. \& Dubois, P.M. (1981) Immunocytological determination of gonadotropic and thyrotropic cells in fetal rat anterior pituitary during normal development and under experimental conditions. Neuroendocrinology 32, 285-294.

Begeot, M., Dubois, M.P. \& Dubois, P.M. (1984) Influence on gonadoliberin on the differentiation of rat gonadotrophs: an in vivo and in vitro study. Neuroendocrinology 38, 217-225.

Bercu, B. (1982) Neutralization of gonadotropinreleasing hormone in neonatal rats with permanent impairment of the hypothalamo-pituitary-testicular axis. Biol. Reprod. 26, 612-619.

Bercu, B.B., Jackson, I.M.D., Sawin, C.T., Safaii, P. \& Reichlin, S. (1977) Permanent impairment of testicular development after transient immunological blockade of endogenous luteinizing hormone releasing hormone in the neonatal rat. Endocrinology 101, $1871-1879$.
Bourguignon, J.-P. \& Franchimont, P. (1984) Puberty-related increase in episodic LHRH release from rat hypothalamus in vitro. Endocrinology 114, 1941-1943.

Cattanach, B.M., Iddon, C.A., Charlton, H.M., Chiappa, S.A. \& Fink, G. (1977) Gonadotrophin releasing hormone deficiency in a mutant mouse with hypogonadism. Nature, Lond. 269, 338-340.

Chan, V., Clayton, R.N., Knox, G. \& Catt, K.J. (1981) Ontogeny of pituitary $\mathrm{GnRH}$ receptors in the rat. Endocrinology 108, 2086-2092.

Charlton, H.M., Halpin, D.M.G., Iddon, C., Rosie, R., Levy G., McDowell, I.F.W., Megson, M.A., Morris, J.F., Bramwell, A., Speight, A., Ward, B.J., Broadhead, J., Davey-Smith, G. \& Fink, G. (1983) The effects of daily administration of single and multiple injections of gonadotrophin-releasing hormone on pituitary and gonadal function in the hypogonadal (hpg) mouse. Endocrinology 113, 535-544.

Chiappa, S.A. \& Fink, G. (1977) Releasing factor and hormonal changes in the hypothalamo-pituitarygonadotrophin and adrenocorticotrophin systems before and after birth and puberty in male, female and androgenised female rats. $J$. Endocr. 77, 211-224.

Chowdhury, M. \& Steinberger, E. (1976) Pituitary and plasma gonadotrophins in foetal and newborn male and female rats. $J$. Endocr. 69, 381-384.

Clarke, I.J. \& Cummins, J.T. (1982) The temporal relationship between gonadotrophin-releasing hormone $(\mathrm{GnRH})$ and luteinizing hormone secretion in ovariectomized ewes. Endocrinology 111, 1737-1739.

Counis, R., Corbani, M. \& Jutisz, M. (1983) Estradiol regulates mRNA's encoding precursors to rat 
lutropin (LH) and follitropin (FSH) subunits. Biochem. Biophys. Res. Commun. 114, 65-72.

Crowley, W.F. \& McArthur, J.W. (1980) Stimulation of the normal menstrual cycle in Kallman's syndrome by pulsatile administration of luteinising hormone releasing hormone (LHRH). J. clin. Endocr. Metab. 51, 173-175.

Dalkin, A.C., Bourne, G.A., Pieper, D.R., Regiani, S. \& Marshall, J.C. (1981) Pituitary and gonadal gonadotrophin-releasing hormone receptors during sexual maturation in the rat. Endocrinology 108, 1658-1664.

Debeljuk, L., Arimura, A. \& Schally, A.V. (1972a) Studies on the pituitary responsiveness to luteinizing hormone-releasing hormone (LH-RH) in intact male rats of different ages. Endocrinology 90, 585-588.

Debeljuk, L., Arimura, A. \& Schally, A.V. (1972b) Pituitary responsiveness to $\mathrm{LH}$-releasing hormone in intact female rats of different ages. Endocrinology 90 , 1499-1502.

Döhler, K.D. \& Wuttke, W. (1974) Serum LH, FSH, prolactin and progesterone from birth to puberty in female and male rats. Endocrinology 94, 1003-1008.

Döhler, K.D. \& Wuttke, W. (1975) Changes with age in levels of serum gonadotrophins, prolactin and gonadal steroids in prepubertal male and female rats. Endocrinology 97, 898-907.

Dullaart, J. (1977) Immature rat pituitary glands in vitro: age- and sex-related changes in luteinising hormone releasing hormone-stimulated gonadotrophin release. J. Endocr. 73, 309-319.

Duncan, J.A., Dalkin, A.C., Barkan, A., Regiani, S. \& Marshall, J.C. (1983) Gonadal regulation of pituitary gonadotrophin-releasing hormone receptors during sexual maturation in the rat. Endocrinology 113, 2238-2246.

Fink, G. \& Smith, G.C. (1971) Ultrastructural features of the developing hypothalamo-hypophysial axis in the rat. Z. Zellforsch. mikrosk. Anat. 119, 208-226.

Fraser, H.M., McNeilly, A.S. \& Popkin, R.M. (1984) Passive immunization against LH-RH: elucidation of the role of LH-RH in controlling LH and FSH secretion and LH-RH receptors. In Immunological Aspects of Reproduction in Mammals, pp. 399-418. Ed. D. B. Crighton. Butterworths, London.

Gibson, M.J., Charlton, H.M., Perlow, M.J., Zimmerman, E.A., Davies, T.F., Krieger, D.T. (1984) Preoptic area brain grafts in hypogonadal (hpg) female mice abolish effects on congenital hypothalamic gonadotrophin-releasing hormone (GnRH) deficiency. Endocrinology 114, 1938-1940.

Giguere, V., Lefebvre, F.-A. \& Labrie, F. (1981) Androgens decrease LHRH binding sites in rat anterior pituitary cells in culture. Endocrinology $\mathbf{1 0 8}$, $350-352$.

Glydon, R. St J. (1957) The development of the blood supply of the pituitary in the albino rat, with special reference to the portal vessels. J. Anat. 91, 237-244.

Goldman, B.D., Quadagno, D.M., Shryne, J. \& Gorski, R.A. (1972) Modification of phallus development and sexual behaviour in rats treated with gonadotrophin antiserum neonatally. Endocrinology 90, 1025-1031

Huhtaniemi, I.T., Stewart, J.M., Channabasavaiah, K., Fraser, H.M. \& Clayton, R.N. (1984a) Pituitarytesticular function in immature rats after treatment with GnRH antagonist, GnRH antiserum and bromocriptine. Molec. cell. Endocr. 34, 137-143.

Huhtaniemi, I.T., Stewart, J.M., Channabasavaiah, K., Fraser, H.M. \& Clayton, R.N. (1984b) Effect of treatment with GnRH antagonist, GnRH antiserum and bromocriptine on pituitary testicular function of adult rats. Molec. cell. Endocr. 34, 127-135.

Kaplan, S.L., Grumbach, M.M. \& Aubert, M.L. (1976) The ontogenesis of pituitary hormones and hypothalamic factors in the human fetus: maturation and central nervous system regulation of anterior pituitary function. Recent Prog. Horm. Res. 32, 161-243.

Ketelslegers, J.-M., Hetzel, W.D., Sherins, R.J. \& Catt, K.J. (1978) Developmental changes in testicular gonadotropin receptors: plasma gonadotropins and plasma testosterone in the rat. Endocrinology 103, 212-221.

Khodr, G.S. \& Siler-Khodr, T.M. (1980) Placental luteinizing hormone-releasing factor and its synthesis. Science, N.Y. 207, 315-317.

King, J.A. \& Millar, R.P. (1979) Heterogeneity of vertebrate luteinizing hormone releasing hormone. Science, N.Y. 206, 67-69.

King, J.A. \& Millar, R.P. (1980) Comparative aspects of luteinizing hormone releasing hormone structure and function in vertebrate phylogeny. Endocrinology 106, $707-714$.

Knobil, E. (1980) The neuroendocrine control of the menstrual cycle. Recent Prog. Horm. Res. 36, 53-58.

Krieger, D.T., Perlow, M.J., Gibson, M.J., Davies, T.F., Zimmerman, E.A., Ferin, M. \& Charlton, H.M. (1982) Brain grafts reverse hypogonadism of gonadotrophin-releasing hormone deficiency. Nature, Lond. 298, 468-471.

Levine, J.E., Pau, F.K.-Y., Ramirez, V.D. \& Jackson, G.L. (1982) Simultaneous measurement of luteinizing hormone-releasing hormone and luteinizing hormone release in unanesthetized, ovariectomized sheep. Endocrinology 111, 1449-1455.

Loumaye, E., Thorner, J. \& Catt, K.J. (1982) Yeast mating pheromone activates mammalian gonadotrophs; evolutionary conservation of a reproductive hormone. Science, N.Y. 218, 1323-1325.

Mason, P., Adams, J., Morris, D.V., Tucker, M., Price, J., Voulgaris, Z., Van der Spuy, Z.M., Sutherland, I., Chambers, G.R., White, S., Wheeler, M.J. \& Jacobs, H.S. (1984) Induction of ovulation with pulsatile luteinizing hormone-releasing hormone. $\mathrm{Br}$. med. $\mathrm{J}$. 288, 181-185.

McDowell, I.F.W., Morris, J.F. \& Charlton, H. (1982) Characterization of the pituitary gonadotroph cells of hypogonadal $(\mathrm{hpg})$ male mice: comparison with normal mice. $J$. Endocr. 95, 321-330.

McDowell, I.F.W., Morris, J.F., Charlton, H.M. \& Fink, G. (1982) Effects of luteinizing hormone releasing hormone on the gonadotrophs of hypogonadal ( hpg) mice. J. Endocr. 95, 331-340.

Menon, V., Butt, W.R., Clayton, R.N., Logan-Edwards, R. \& Lynch, S.S. (1984) Pulsatile administration of GnRH for the treatment of hypogonadotrophic hypogonadism. Clin. Endocr. 21, 223-232.

Millar, R.P. \& King, J.A. (1983) Synthesis, luteinizing hormone-releasing activity, and receptor binding of 
chicken hypothalamic luteinizing hormone-releasing hormone. Endocrinology 113, 1364-1369.

Miyachi, Y., Nieschlag, E. \& Lipsett, M.B. (1973) The secretion of gonadotropins and testosterone by the neonatal male rat. Endocrinology $92,1-5$.

Negro-Vilar, A., Krulich, L. \& McCann, S.M. (1973) Changes in serum prolactin and gonadotropins during sexual development of the male rat. Endocrinology 93, 660-664.

Nemeskeri, A., Halasz, B. \& Kurcz, M. (1983) Ontogenesis of the rat hypothalamo-adenohypophysial system and inherent capacity of the fetal pituitary to differentiate into hormone synthesizing and releasing cells. In The Anterior Pituitary Gland, pp. 341-354. Ed. A. S. Bhatnagar. Raven Press, New York.

Nilson, J.H., Nejedlik, M.T., Virgin, J.B., Crowder, M.E. \& Nett, T.M. (1983) Expression of $\alpha$ subunit and luteinizing hormone $\beta$ genes in the ovine pituitary. $J$. biol. Chem. 258, 12087-12090.

Odell, W.D. \& Swerdloff, R.S. (1976) Etiologies of sexual maturation: a model system based on the sexually maturing rat. Recent Prog. Horm. Res. 32, 245-288.

Ojeda, S.R., Jameson, H.E. \& McCann, S.M. (1977) Developmental changes in pituitary responsiveness to luteinizing hormone-releasing hormone (LHRH) in the female rat: ovarian-adrenal influence during the infantile period. Endocrinology 100, 440-451.

Ojeda, S.R., Andrews, W.W., Advis, J.P. \& Smith-White, S. (1980) Recent advances in the endocrinology of puberty. Endocrine Reviews 1, 228-257.

Ross, D.L., Loriaux, D.L. \& Cutler, G.B. (1983) Developmental changes in neuroendocrine regulation of gonadotrophin secretion in gonadal dysgenesis. J. clin. Endocr. Metab. 57, 288-293.

Sharpe, R.M., Fraser, H.M., Cooper, I. \& Rommerts,
F.F.G. (1982) The secretion, measurement and function of a testicular LHRH-like factor. Ann N.Y. Acad. Sci. 383, 272-294.

Sherwood, N., Eiden, E., Brownstein, M., Spiess, J., Rivier, J. \& Vale, W. (1983) Characterization of a teleost gonadotrophin-releasing hormone. Proc. natn. Acad. Sci. U.S.A. 80, 27942798.

Siler-Khodr, T.M. \& Khodr, G.S. (1978) Content of luteinizing hormone releasing factor in the human placenta. Am. J. Obstet. Gynec. 130, 216-219.

Styne, D.M. \& Grumbach, M.M. (1978) Puberty in the male and female: its physiology and disorders. In Reproductive Endocrinology, pp. 189-240. Eds S. S. C. Yen \& R. B. Jaffe. W. B. Saunders, London.

Tan, L. \& Rousseau, P. (1982) The chemical identity of the immunoreactive LHRH-like peptide biosynthesized in the human placenta. Biochem. Biophys. Res. Commun. 109, 1061-1071.

Vogel, D.L., Gunsalus, G.L., Bercu, B.B., Musto, N.A. \& Bardin, C.W. (1983) Sertoli cell maturation is impaired by neonatal passive immunization with antiserum to luteinizing hormone-releasing hormone. Endocrinology 112, 1118-1121.

Wildt, L., Marshall, G. \& Knobil, E. (1980) Experimental induction of puberty in the infantile female rhesus monkey. Science, N.Y. 207, 1373-1375.

Young, L.S., Speight, A., Charlton, H.M. \& Clayton, R.N. (1983) Pituitary gonadotropin-releasing hormone receptor regulation in the hypogonadotrophic hypogonadal (hpg) mouse. Endocrinology 113, 55-61.

Young, L.S., Detta, A., Clayton, R.N., Jones, A. \& Charlton, H.M. (1985) Pituitary and gonadal function in hypogonadotrophic hypogonadal ( $h p g$ ) mice bearing hypothalamic implants. J. Reprod. Fert. 74, 247-255.

Received 4 April 1985 